\title{
Impact of timing of feed delivery on the behavior and productivity of dairy cows
}

\author{
M. T. M. King, R. E. Crossley, and T. J. DeVries ${ }^{1}$ \\ Department of Animal Biosciences, University of Guelph, 50 Stone Road East, Guelph, ON, N1G 2W1, Canada
}

\section{ABSTRACT}

The objective of this work was to assess the effect of timing of feed delivery on the behavior and productivity of cows milked 3 times per day. Twelve lactating Holstein dairy cows (4 primiparous and 8 multiparous), milked 3 times per day (at 1400, 2100, and $0700 \mathrm{~h}$ ), were individually assigned and exposed to each of 2 treatments (over 21-d periods) in a replicated crossover design. Treatments were the manipulation of timing of TMR delivery, 2 times per day, in relation to milking time: (1) feeding at milking time (at 1400 and $0700 \mathrm{~h}$ ), and (2) feeding halfway between milking times (at 1730 and $1030 \mathrm{~h}$ ). Milk production, feeding, sorting, and rumination behavior were monitored for each animal for the last $7 \mathrm{~d}$ of each treatment period. Milk samples were collected for 2 of the last $4 \mathrm{~d}$ of each period for milk component analysis. With a feed delivery delay, dry matter intake (DMI) tended to be lower (26.5 vs. $27.2 \mathrm{~kg} / \mathrm{d}$ ). Although no difference was found in feeding time $(224.2 \mathrm{~min} / \mathrm{d})$, cows fed with a delay consumed their feed more slowly (0.12 vs. $0.13 \mathrm{~kg}$ of dry matter/ min) in more frequent meals (10.0 vs. 9.1 meals/d), which were smaller in size (2.8 vs. $3.1 \mathrm{~kg} /$ meal) and tended to be shorter in duration (26.7 vs. $30.1 \mathrm{~min} /$ meal). Cows fed at milking sorted for long particles (102.3\%), whereas cows fed with a delay did not sort for or against those particles. Cows sorted for medium particles to a similar extent $(102.5 \%)$ on each treatment. Cows did not sort for or against short particles on either treatment. Sorting against fine particles was observed, to a similar extent (97.1\%), on both treatments. Rumination time $(8.9 \mathrm{~h} / \mathrm{d})$ and lying time $(9.5$ $\mathrm{h} / \mathrm{d}$ ) were similar between treatments. Cows without fresh feed at the $1400 \mathrm{~h}$ milking tended to stand for less time following that milking (71.0 vs. $94.0 \mathrm{~min})$, whereas cows without fresh feed at the $0700 \mathrm{~h}$ milking stood for less time following that milking (66.3 vs. 87.8

Received May 6, 2015.

Accepted October 30, 2015.

${ }^{1}$ Corresponding author: tdevries@uoguelph.ca min). No difference in this latency to lie down was seen at the $2100 \mathrm{~h}$ milking. Milk yield $(48.0 \mathrm{~kg} / \mathrm{d})$, milk fat content $(3.64 \%)$, and milk protein content $(2.86 \%)$ were similar between treatments. Given the tendency for a difference in DMI and no change in yield, efficiency of production was improved with a feed delay (1.93 vs. $1.80 \mathrm{~kg}$ of milk/ $\mathrm{kg}$ of DMI). These data suggest that moving the timing of feed delivery resulted in cows consuming their feed more slowly in smaller, more frequent meals, contributing to an improvement in efficiency of production.

Key words: feed delivery, meal pattern, behavior

\section{INTRODUCTION}

Enhancing health and productivity involves the management of cow feeding and lying behavior patterns. Ruminal health is optimized when cows consume smaller meals, slowly and frequently, while minimizing feed sorting (Krause and Oetzel, 2006; DeVries et al., 2008). Udder health may be improved by controlling the duration of time cows spend standing after milking (Barnouin et al., 2004; DeVries et al., 2010; Watters et al., 2014).

Fresh feed delivery has an effect on both meal patterning and latency to lie down after milking. Feed delivery is known to stimulate feeding activity, with frequent delivery of TMR resulting in a more even distribution of feeding activity throughout the day (DeVries et al., 2003a, 2005; DeVries and von Keyserlingk, 2005). Furthermore, cows will remain standing longer after milking when feed is delivered close to a milking time (Tyler et al., 1997; DeVries et al., 2010; Watters et al., 2014).

It is possible that the delivery of feed can be delayed from the time of milking to encourage cows to eat more often, by taking advantage of both feeding stimuli (i.e., feed provision and return from milking). DeVries and von Keyserlingk (2005) demonstrated that with 2 times per day milking and feeding, daily feeding time increased by $12.5 \%$ with a 6 -h feed delay after milking. In the same study, standing duration after milking was reduced from $65.7 \mathrm{~min}$, when fed at the time of milking, to $45.1 \mathrm{~min}$ when fed $6 \mathrm{~h}$ after milking. Shortened 
latency to lie down may be associated with a higher risk of acquiring new IMI (DeVries et al., 2010; Watters et al., 2014). It is unknown if lying latencies would be further reduced with a feed delay when cows are milked 3 times per day. Additionally, DeVries and von Keyserlingk (2005) focused on behavioral responses at a group level and did not record DMI or meal patterns for individual cows. It is, thus, unclear how a feed delay after milking affects feeding activity at the individual cow level. As feeding behavior varies greatly for individual cows within a group (Melin et al., 2005), it is important to understand how management practices, such as timing of feed delivery, influence that behavior at a cow level.

Therefore, the objective of this study was to assess the effect of timing of feed delivery on behavior and productivity of cows milked 3 times per day. It was hypothesized that delaying feed delivery from milking time would result in cows consuming more frequent, smaller meals by providing multiple stimuli for feeding across the day. Furthermore, we predicted that the latency to lie down after milking would be reduced when cows did not have fresh feed delivered at the time of milking.

\section{MATERIALS AND METHODS}

\section{Animals and Housing}

This study observed 12 lactating Holstein dairy cows, including 4 primiparous and 8 multiparous individuals (parity $=3.0 \pm 1.3$; mean $\pm \mathrm{SD}$ ). Cows were $52 \pm$ 23 DIM and producing $46.6 \pm 8.5 \mathrm{~kg} / \mathrm{d}$, and weighed $668.2 \pm 58.2 \mathrm{~kg}$ at enrollment into the study. Cows were housed 6 at a time in a freestall research pen at the University of Guelph, Kemptville Campus Dairy Education and Innovation Center (Kemptville, ON, Canada). The research pen contained 6 freestalls with waterbeds (DCC Waterbeds, Advanced Comfort Technology Inc., Reedsburg, WI), which were bedded with wood shavings; bedding was replaced as needed. Manure was manually scraped from the stalls at 1400, 2100, and $0700 \mathrm{~h}$, such that it was within reach of the alley scrapers. Cows were milked 3 times per day (at 1400, 2100, and $0700 \mathrm{~h}$ ) using an automatic milking system (AMS; Lely A3 Next, Lely Industries N.V., Maassluis, the Netherlands). At the specified milking times, cows were moved from the research pen into a small holding area adjacent to the AMS. Cows were milked individually and sequentially, receiving no supplemental feed from the AMS and returning to their pen individually following milking. Animal use complied with the Canadian Council on Animal Care guidelines (CCAC, 2009) and was approved by the Animal Care Committee at the University of Guelph.

\section{Experimental Design}

Sample size and power analysis were used to calculate the number of animals needed (Morris, 1999) to detect a $14 \%$ level of observed difference for the primary outcome variables, including behavior, DMI, and sorting, as well as milk production and composition. Estimates of variation for these variables were based on previously reported values (Leonardi and Armentano, 2003; Hart et al., 2013, 2014). Cows were divided into 2 groups of 6 , which were balanced according to parity, DIM, and milk production. Within each group, cows were individually assigned and exposed to each of 2 treatments in a replicated crossover design (with groups replicated over time), with 21-d treatment periods (including $14 \mathrm{~d}$ of adaptation to the feeding schedule, before a 7 -d data collection period). Treatments were the manipulation of timing of fresh feed delivery, 2 times per day, in relation to milking time: (1) feed delivery at milking time (at 1400 and $0700 \mathrm{~h}$ ) and (2) feed delivery with delay, halfway between milking times (at 1730 and 1030 $\mathrm{h}$, with a 3.5-h delay from milking time). Within each group, cows were alternately, and individually, assigned to treatments within each period. Thus, across all 12 cows, the order of treatment exposure was balanced. The experiment was conducted between May 19 and August 21, 2014, with an average environmental temperature of $17.9 \pm 2.7^{\circ} \mathrm{C}$.

\section{Feeding Procedure}

Within each group, cows were each assigned to 1 individual feed bin (Insentec RIC, Marknesse, the Netherlands), which measured feed intake and feeding behavior, as validated by Chapinal et al. (2007). Cows trained for $3 \mathrm{~d}$ before treatment allocation to access their unique feed bin. Cows were fed a TMR (Table 1) formulated to meet the requirements for $40 \mathrm{~kg}$ production according to the NRC (2001) nutrient recommendations for high-producing cows. The TMR (without grain supplement) was prepared once per day in a TMR mixer (Jaylor 4425, Jaylor Fabricating, Orton, ON, Canada) and delivered on a conveyor into a motorized feed cart (Rovibec 530, Ste-Monique Co., Nicolet, QC, Canada) at $1200 \mathrm{~h}$. The appropriate amount of grain supplement was then weighed on a scale (model ES30R, Ohaus Corporation, Pine Brook, NJ) and mixed with the TMR for $4 \mathrm{~min}$ in the feed cart. Daily feed allotments were separated into 2 feedings, with the larger feeding $(\sim 70 \%)$ in the afternoon and the smaller feed- 
Table 1. Ingredient and chemical composition of the experimental ration (mean $\pm \mathrm{SD}$ )

\begin{tabular}{|c|c|}
\hline Composition & Diet \\
\hline \multicolumn{2}{|l|}{ Ingredient (\% of DM) } \\
\hline Corn silage $^{1}$ & 24.2 \\
\hline Haylage $\# 1^{2}$ & 18.0 \\
\hline Haylage $\# 2^{3}$ & 18.1 \\
\hline High moisture corn & 13.5 \\
\hline Protein concentrate pellet ${ }^{4}$ & 11.5 \\
\hline Grain supplement pellet $^{5}$ & 14.7 \\
\hline \multicolumn{2}{|l|}{ Chemical composition $^{6}$} \\
\hline $\mathrm{DM}(\%)$ & $55.8 \pm 2.00$ \\
\hline $\mathrm{OM}(\%$ of $\mathrm{DM})$ & $92.2 \pm 0.82$ \\
\hline $\mathrm{CP}(\%$ of $\mathrm{DM})$ & $16.7 \pm 0.26$ \\
\hline $\mathrm{ADF}(\%$ of $\mathrm{DM})$ & $19.9 \pm 0.92$ \\
\hline $\mathrm{NDF}(\%$ of $\mathrm{DM})$ & $30.8 \pm 1.21$ \\
\hline Starch (\% of DM) & $22.0 \pm 2.53$ \\
\hline NFC ( $\%$ of DM) & $42.2 \pm 1.44$ \\
\hline $\mathrm{Ca}(\%$ of $\mathrm{DM})$ & $0.88 \pm 0.03$ \\
\hline $\mathrm{P}(\%$ of $\mathrm{DM})$ & $0.45 \pm 0.03$ \\
\hline $\mathrm{NE}_{\mathrm{L}}(\mathrm{Mcal} / \mathrm{kg}$ of DM $)$ & $1.65 \pm 0.03$ \\
\hline
\end{tabular}

${ }^{1}$ Corn silage had a DM of $39.8 \pm 6.09 \%$ and a chemical composition (DM basis) of $6.4 \pm 0.22 \% \mathrm{CP}, 23.4 \pm 2.52 \% \mathrm{ADF}, 38.7 \pm 4.33 \%$ $\mathrm{NDF}$, and $33.2 \pm 5.09 \%$ starch.

${ }^{2}$ Red clover (95\%) and orchardgrass (5\%) haylage had a DM of 47.7 $\pm 3.27 \%$ and a chemical composition (DM basis) of $18.8 \pm 1.77 \% \mathrm{CP}$, $35.2 \pm 3.51 \% \mathrm{ADF}$, and $48.0 \pm 7.00 \% \mathrm{NDF}$.

${ }^{3}$ Red clover (75\%) and timothy/orchardgrass (25\%) haylage had a DM of $55.1 \pm 8.09 \%$ and a chemical composition (DM basis) of $20.6 \pm$ $1.63 \% \mathrm{CP}, 32.2 \pm 1.56 \% \mathrm{ADF}$, and $40.4 \pm 2.49 \% \mathrm{NDF}$.

${ }^{4}$ Supplied by Dundas Feed \& Seed Ltd. (Winchester, Ontario, Canada) including the ingredients (as is) 35 to $40 \%$ corn distillers, 18 to $33 \%$ soybean meal, 8 to $24 \%$ canola, $6.8 \%$ calcium carbonate, 1.5 to $7.5 \%$ feather meal, $2.4 \%$ salt, $2.0 \%$ sodium bicarbonate, 0 to $3 \%$ tallow, $0.8 \%$ dicalcium phosphate, $0.4 \%$ magnesium oxide, $0.144 \%$ trace minerals, and $0.046 \%$ vitamins.

${ }^{5}$ Supplied by Dundas Feed \& Seed Ltd. including the ingredients 20 to $40 \%$ wheat shorts, 16 to $34 \%$ soybean meal, 12 to $32 \%$ corn, 4 to $14 \%$ corn distillers grains, 0 to $10 \%$ oat by-product, $3 \%$ molasses, $2.0 \%$ dry fat, $0.6 \%$ calcium carbonate, $0.9 \%$ dicalcium phosphate, $0.3 \%$ choline chloride, $0.4 \%$ salt, $0.0084 \%$ vitamins, $0.0569 \%$ trace minerals, $1.25 \%$ pellet binder, and $0.125 \%$ flavor/attractant.

${ }^{6}$ Values were obtained from chemical analysis of TMR samples. OM $=$ $100-\%$ ash. $\mathrm{NFC}=100-(\% \mathrm{CP}+\% \mathrm{NDF}+\%$ fat $+\%$ ash $)$. The $\mathrm{NE}_{\mathrm{L}}$ was calculated based on NRC (2001) equations.

ing $(\sim 30 \%)$ delivered the following morning. Feed allotments for the second (morning) feeding were weighed, using a scale (model ES30R, Ohaus Corporation), into sealed containers and stored until they were delivered the next morning.

Because afternoon fresh feed access began at either 1400 or $1730 \mathrm{~h}$, the start of each data collection day (for each variable) began at $1400 \mathrm{~h}$, and therefore, afternoon feedings were considered the first feeding whereas morning feedings were the second feeding of each data collection day. Feed access was denied for $1 \mathrm{~h}$ each day before the first feeding (feed bins were closed at 1300 or $1630 \mathrm{~h}$, depending on the treatment). During this time, refusals were discarded and fresh feed was delivered manually. Feed offered to each cow was adjusted daily to target a refusal rate of $10 \%$.

\section{Behavioral Data Collection}

To monitor feeding behavior, the Insentec system electronically recorded the number of visits to each bin, the duration of those visits, and the amount of feed consumed during each visit. For each 7-d data collection period, these data were summarized to calculate daily DMI $(\mathrm{kg} / \mathrm{d})$, daily feeding time $(\mathrm{min} / \mathrm{d})$, and average feeding rate $(\mathrm{kg} / \mathrm{min})$ of each cow.

To monitor standing and lying behavior, data loggers (HOBO Pendant G Logger, Onset Computer Corporation, Pocasset, MA), attached below the rear hock of each animal, measured leg orientation at 1-min intervals during the 7-d data collection periods, as previously validated by Ledgerwood et al. (2010). On d 14 of each treatment period, data loggers were attached using veterinary bandaging tape (Vetrap Bandaging Tape, 3M, London, ON, Canada) while the cow was restrained in a lying stall. Data collected were used to calculate daily standing and lying duration $(\mathrm{min} / \mathrm{d})$, in addition to the frequency (no./d) and length ( $\mathrm{min} /$ bout) of each bout. The latency to lie down after milking (min) was calculated as the difference in time between the end of milking for each cow and the first recorded instance when the cow lay down after milking.

To monitor rumination behavior, data were collected using automatic rumination detection loggers on the neck collar of each cow (Lely Qwes-HR collars, Lely Industries N.V.). Loggers recorded the time spent ruminating in 2-h intervals (as validated by Schirmann et al., 2009). These data were transferred at each milking using an automatic reader located in the AMS, and were then summarized by day and 2-h interval for each 7-d data collection period.

\section{Feed Sampling and Analyses}

During each 7-d data collection period, duplicate samples of refusals were collected during the $1 \mathrm{~h}$ of blocked feed access: one sample to determine DM and the other to analyze particle size for feed sorting. One sample of fresh feed was taken at both feedings for DM and nutrient content determination, in addition to a second sample taken at the first feeding to analyze particle size. Component feed samples were collected on d 1,8 , and 15 of each treatment period for DM, chemical, and particle size analyzes. Upon collection, samples were immediately frozen at $-20^{\circ} \mathrm{C}$ until later analysis.

Samples for particle size determination (Table 2) were separated using a 3 -screen $(19,8,1.18 \mathrm{~mm})$ Penn 
Table 2. Particle size distribution ${ }^{1}$ and nutrient content of the particle fractions of the experimental diet $($ mean $\pm \mathrm{SD})$

\begin{tabular}{lr}
\hline Item & Diet \\
\hline \% DM retained on screen & $1.8 \pm 0.55$ \\
Long & $45.0 \pm 2.92$ \\
Medium & $37.0 \pm 2.28$ \\
Short & $16.2 \pm 1.70$ \\
Fine & \\
NDF (\% of screen DM) & $53.0 \pm 3.77$ \\
Long & $35.0 \pm 1.34$ \\
Medium & $29.1 \pm 2.00$ \\
Short & $21.7 \pm 1.39$ \\
Fine & \\
Starch (\% of screen DM) & $4.7 \pm 0.56$ \\
Long & $20.1 \pm 1.36$ \\
Medium & $24.6 \pm 4.58$ \\
Short & $29.2 \pm 2.93$ \\
Fine & \\
CP $\%$ of screen DM) & $11.3 \pm 0.33$ \\
Long & $14.3 \pm 0.14$ \\
Medium & $16.7 \pm 0.51$ \\
Short & $22.2 \pm 0.73$ \\
Fine &
\end{tabular}

${ }^{1}$ Particle size determined by the Penn State Particle Separator, which has a 19-mm screen (long), 8-mm screen (medium), 1.18-mm screen (short), and a pan (fine).

State Particle Separator (PSPS; Kononoff et al., 2003) to divide samples into 4 fractions [long $(>19 \mathrm{~mm})$, me$\operatorname{dium}(<19,>8 \mathrm{~mm})$, short $(<8,>1.18 \mathrm{~mm})$, and fine $(<1.18 \mathrm{~mm})$ particles]; all of these separated samples were individually dried at $55^{\circ} \mathrm{C}$ for $48 \mathrm{~h}$.

Samples for DM and chemical analyses were also ovendried at $55^{\circ} \mathrm{C}$ for $48 \mathrm{~h}$. These samples, and all fresh feed particle fractions, were ground through a 1-mm screen (Wiley Mill, Arthur H. Thomas Co., Philadelphia, PA). Dried and ground samples were sent to Cumberland Valley Analytical Services Inc. (Maugansville, MD) for analysis of $\mathrm{DM}\left(135^{\circ} \mathrm{C}\right.$; AOAC International, 2000; method 930.15$)$, ash $\left(535^{\circ} \mathrm{C}\right.$; AOAC International, 2000 ; method 942.05), ADF (AOAC International, 2000; method 973.18), NDF with heat-stable $\alpha$-amylase and sodium sulfite (Van Soest et al., 1991), starch (Hall, $2009)$, and $\mathrm{CP}(\mathrm{N} \times 6.25$; AOAC International 2000; method 990.03; Leco FP-528 Nitrogen Analyzer, Leco, St. Joseph, MI). Nutrient composition of the TMR and its particle fractions are found in Tables 1 and 2 , respectively.

\section{Milk Production and Components}

The AMS automatically recorded milk yield at each milking during the 7-d data collection periods (Lely A3 Next, Lely Industries N.V.). Milk samples were collected, on d 18 and 20 of each treatment period, by the Lely Shuttle Sampling Device (Lely Industries N.V.). Milk samples were sent to a DHI testing laboratory
(CanWest DHI, Guelph, Ontario, Canada) for analysis of milk fat and protein percentage, SCC, and MUN using a near-infrared analyzer (FOSS System 4000 Infrared Transmission Analyzer, Foss, Hillerød, Denmark).

For those days where milk components were measured, the yield of $4 \% \mathrm{FCM}(\mathrm{kg} / \mathrm{d})$ was calculated $(\mathrm{NRC}, 2001)$ as $0.4 \times$ milk yield $(\mathrm{kg} / \mathrm{d})+15.0 \times$ fat yield $(\mathrm{kg} / \mathrm{d})$. Energy-corrected milk was calculated using the following equation: $\mathrm{ECM}=(0.327 \times \mathrm{kg}$ of milk $)$ $+(12.95 \times \mathrm{kg}$ of fat $)+(7.2 \times \mathrm{kg}$ of protein) $($ Tyrrell and Reid, 1965). Milk production efficiency was determined by calculating the kilograms of milk, $4 \%$ FCM yield, and ECM yield per kilogram of DMI for each treatment period.

\section{Calculations and Statistical Analyses}

Feeding bouts were grouped into meals using individual meal criteria (minimum inter-meal interval) for each cow for each treatment, as per that recommended by DeVries et al. (2003b). Meal criteria were determined, as described by DeVries et al. (2003b), using a software package (MIX 3.1.3; MacDonald and Green, 1988) to fit a mixture of normal distributions to the distributions of $\log _{10}$-transformed time intervals between moments of feeding during the 7-d data collection periods. These meal criteria were then used to calculate meal frequency (meals/d), by counting the number of intervals between feeding bouts that exceeded the criterion. Meal duration ( $\mathrm{min} / \mathrm{meal})$ was calculated from the start time of the first feeding bout until the end time of the last feeding bout at which time the meal criterion was exceeded. Meal size $(\mathrm{kg} / \mathrm{meal})$ was calculated by dividing DMI by meal frequency. Meal duration and meal size were also calculated for the first meal consumed after each milking based on the calculated meal criteria for each cow and period.

Feed sorting was calculated as the actual DMI of each fraction of PSPS expressed as a percentage of the predicted DMI of that fraction (Leonardi and Armentano, 2003). Realized intake values for each individual fraction were calculated as the difference between the DM amount of each fraction in the offered feed versus that in the refused feed. The predicted intake for each individual fraction was calculated as the product of the DMI of the total diet multiplied by the DM percentage of that fraction in the offered diet. Values equal to $100 \%$ indicate no sorting, $<100 \%$ indicate selective refusals (sorting against), and $>100 \%$ indicate preferential consumption (sorting for).

Prior to analyses, all data were screened for normality using the UNIVARIATE procedure of SAS (SAS Institute Inc., 2013). Data for SCC were right-skewed 
and, thus, were transformed by taking the natural logarithm.

All behavioral and production data collected for each cow during each 7-d data collection period were summarized to create one value per treatment for each cow. Cows were considered experimental units as treatments were applied at the cow level. These data were analyzed using the MIXED procedure of SAS (SAS Institute Inc., 2013). The final model included the fixed effects of period, order of treatment exposure (sequence), and treatment. The random effects were group and cow within order of treatment exposure and group. Degrees of freedom for fixed effects were estimated using the Kenward-Roger option in the MODEL statement. To test whether feed sorting occurred, sorting activity for each fraction of the PSPS was summarized by treatment and tested for a difference from 100 using $t$-tests using the above mentioned model.

Data for DMI, feeding time, and feeding rate were also summarized on an hourly basis, whereas ruminating time was summarized on a 2 -h basis, for each animal on each treatment. Differences among treatments in the distribution of these variables over a 24 -h period were analyzed using the MIXED procedure of SAS, treating hour as a repeated measure. The final model included the fixed effects of period, order of treatment exposure, hour, treatment, and hour $\times$ treatment interaction. Other interactions of the fixed effects were tested in the initial model and were not significant; therefore, they were removed from the final model. The random effects were group and cow within order of treatment exposure and group. Cow within order of treatment exposure and group was included in the model as the subject of the repeated statement. Compound symmetry was selected as the covariance structure on the basis of best fit according to Schwarz's Bayesian information criterion. Degrees of freedom were estimated using the Kenward-Roger option in the MODEL statement. All values reported are least squares means. Significance was declared at $P \leq 0.05$, and trends reported if 0.05 $<P \leq 0.10$.

\section{RESULTS}

Whereas no difference was found in total feeding time (224.2 min/d) between treatments (Table 3), differences in patterning of feed consumption over the course of the day were observed. Regardless of treatment, hourly DMI (Figure 1) increased after each milking (1400, 2100 , and $0700 \mathrm{~h})$. A treatment $\times$ hour interaction $(P$ $<0.001)$ revealed that cows fed at milking time spent more time feeding (Figure 2) and consumed more DM (Figure 1) in the hour after each milking than cows without fresh feed. When cows were fed with a delay from milking time, both DMI (Figure 1) and feeding time (Figure 2) per hour also increased after the 1730 $\mathrm{h}$ feeding, and to a much lesser extent, after the 1030 $\mathrm{h}$ feeding. Cows consumed their feed, on average, at a slower rate when fed with a delay from milking time (Table 3). A treatment $\times$ hour interaction $(P=0.001)$ indicated that feeding rate varied between treatments throughout the day; we observed an increase in feeding rate for cows fed at milking at 1400 and $0700 \mathrm{~h}$ (Figure 3), whereas it was elevated at $1730 \mathrm{~h}$ for cows fed with a delay from milking.

Meal criteria were shorter, and meals were more frequent, smaller, and tended to be shorter when cows were fed with a delay from milking, yet no treatment effect was found on length of intervals between meals (Table 3). Both the size and length of the first meal after the 1400 and $0700 \mathrm{~h}$ milkings were lesser when cows were fed with a delay from milking time. No treatment differences were seen for the first meal following the milking at $2100 \mathrm{~h}$, when no fresh feed was delivered to cows on either treatment.

No treatment effect was seen on average meal size of the first meal following the $1400 \mathrm{~h}$ feeding/milking (5.0 $\mathrm{kg})$ compared with the $1730 \mathrm{~h}$ feeding $(5.9 \mathrm{~kg}$; SED = $0.54 ; P=0.14)$. Similarly, no difference was found in meal length following the $1400 \mathrm{~h}$ feeding/milking (43.7 min) compared with the $1730 \mathrm{~h}$ feeding (47.9 min; SED $=3.89 ; P=0.29)$. No difference was found between the size of the first meal following the $0700 \mathrm{~h}$ feeding/ milking $(3.5 \mathrm{~kg})$ and the $1030 \mathrm{~h}$ feeding $(3.1 \mathrm{~kg}$; SED $=0.30, P=0.14)$. Average meal length was longer following the $0700 \mathrm{~h}$ feeding/milking (40.3 min) when compared with cows fed at $1030 \mathrm{~h}$ (31.1 min; SED = 2.80, $P=0.009)$.

Cows did not sort for or against long particles $(>19$ $\mathrm{mm}$ ) when fed with a delay from milking time; however, they did sort for those particles when fed at milking time (Table 4). Cows sorted for medium particles $(<19,>8 \mathrm{~mm})$ to a similar extent on each treatment. Cows did not sort for or against short particles $(<8$, $>1.18 \mathrm{~mm}$ ) on either treatment. Sorting against fine $(<1.18 \mathrm{~mm})$ particles was observed, to a similar extent, on both treatments. Feed refusal rates were similar between treatments (Table 3).

Daily lying time and frequency of lying bouts did not differ between treatments (Table 3 ). Cows without fresh feed at the $1400 \mathrm{~h}$ milking tended to stand for less time following that milking, whereas cows without fresh feed at the $0700 \mathrm{~h}$ milking stood for less time following that milking. No difference in this latency to lie down was seen at the $2100 \mathrm{~h}$ milking, when no fresh feed was delivered to cows on either treatment. Rumination time was similar between treatments (Table 3); however, a treatment $\times$ hour interaction $(P=0.006)$ indicated 


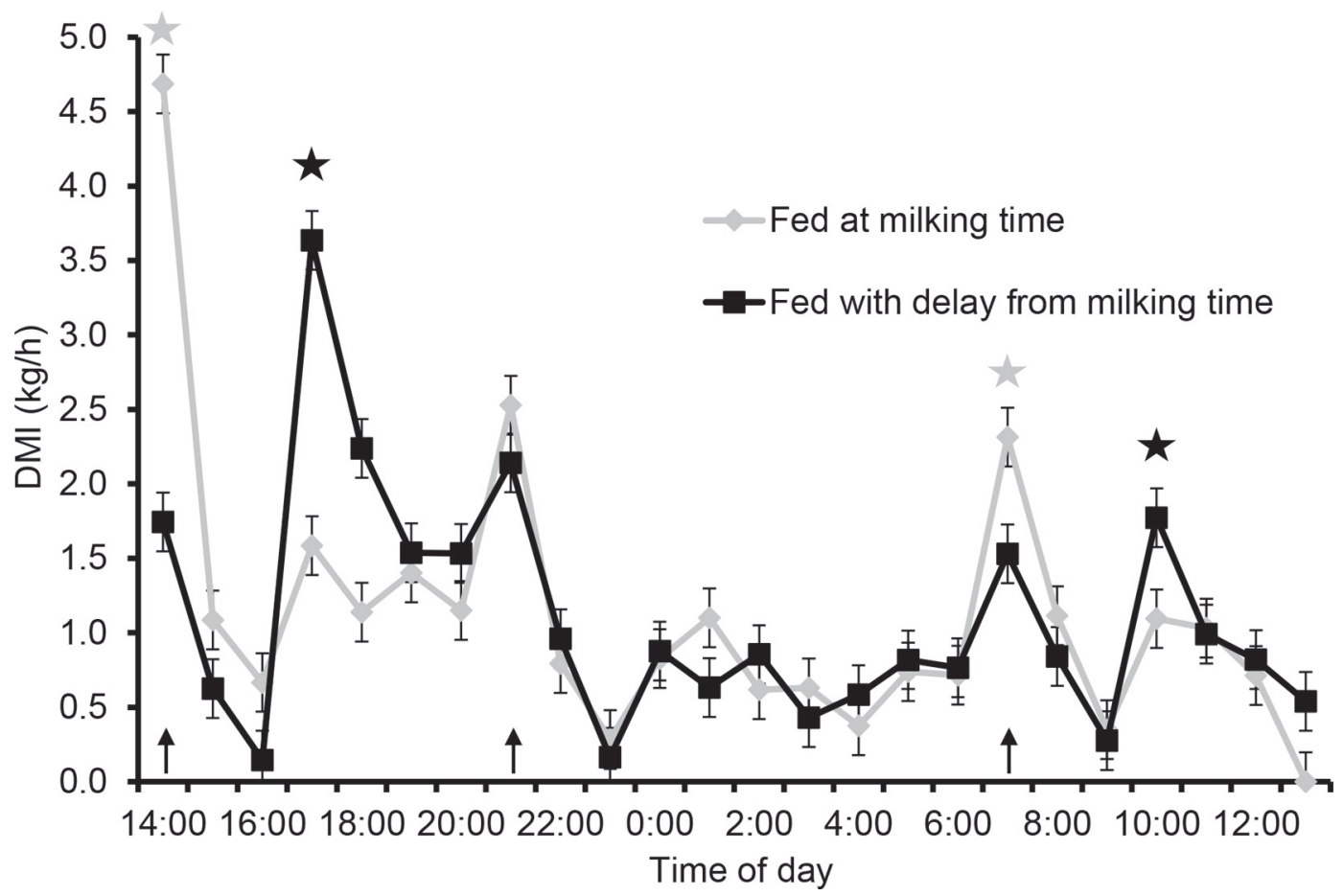

Figure 1. Hourly average DMI \pm standard error $(\mathrm{kg})$ of lactating dairy cows fed 2 times per day: (1) at milking time (at 1400 and $0700 \mathrm{~h}$, denoted with gray star) or (2) fed with delay from milking time (at 1730 and $1030 \mathrm{~h}$, denoted with black star). Cows were milked 3 times per day at 1400,2100 , and $0700 \mathrm{~h}$ (denoted with $\uparrow$ ). Data are averaged over $7 \mathrm{~d}$ for 12 cows on each treatment.

Table 3. Effect of timing of feed delivery on DMI, feeding behavior, rumination, lying behavior, and latency to lie down after milking

\begin{tabular}{|c|c|c|c|c|}
\hline \multirow[b]{2}{*}{ Item } & \multicolumn{2}{|c|}{ Treatment $^{2}$} & \multirow[b]{2}{*}{$\mathrm{SED}^{3}$} & \multirow[b]{2}{*}{$P$-value } \\
\hline & $\begin{array}{l}\text { Fed at } \\
\text { milking }\end{array}$ & $\begin{array}{l}\text { Delayed } \\
\text { feeding }\end{array}$ & & \\
\hline Feeding time $(\mathrm{min} / \mathrm{d})$ & 223.4 & 224.9 & 6.32 & 0.82 \\
\hline Feeding rate $(\mathrm{kg} / \mathrm{min})$ & 0.13 & 0.12 & 0.0051 & 0.03 \\
\hline Meal criterion (min) & 22.4 & 15.6 & 2.04 & 0.026 \\
\hline Meal frequency (no./d) & 9.1 & 10.0 & 0.40 & 0.042 \\
\hline Interval between meals ( $\min$ ) & 134.8 & 134.8 & 7.13 & 0.99 \\
\hline Meal size (kg of DM/meal) & 3.1 & 2.8 & 0.14 & 0.048 \\
\hline Meal duration (min/meal) & 30.1 & 26.7 & 1.72 & 0.06 \\
\hline \multicolumn{5}{|l|}{ Postmilking meal measurements } \\
\hline Length at $1400 \mathrm{~h}(\min )$ & 47.1 & 22.1 & 4.57 & $<0.001$ \\
\hline Size at $1400 \mathrm{~h}(\mathrm{~kg})$ & 5.5 & 2.0 & 0.55 & $<0.001$ \\
\hline Length at $2100 \mathrm{~h}(\min )$ & 37.7 & 28.8 & 6.23 & 0.17 \\
\hline Size at $2100 \mathrm{~h}(\mathrm{~kg})$ & 3.2 & 3.1 & 0.15 & 0.24 \\
\hline Length at $0700 \mathrm{~h}(\mathrm{~min})$ & 40.3 & 26.2 & 3.33 & 0.002 \\
\hline Size at $0700 \mathrm{~h}(\mathrm{~kg})$ & 3.5 & 2.4 & 0.21 & $<0.001$ \\
\hline Rumination (min/d) & 533.1 & 538.2 & 11.52 & 0.66 \\
\hline Lying time $(\mathrm{h} / \mathrm{d})$ & 9.3 & 9.7 & 0.36 & 0.30 \\
\hline Lying bouts (no./d) & 9.7 & 9.6 & 0.33 & 0.63 \\
\hline \multicolumn{5}{|c|}{ Latency to lie down after milking (min/d) } \\
\hline At $1400 \mathrm{~h}(\min )$ & 94.0 & 71.0 & 12.1 & 0.07 \\
\hline At $2100 \mathrm{~h}(\mathrm{~min})$ & 70.3 & 64.5 & 8.07 & 0.48 \\
\hline At $0700 \mathrm{~h}(\min )$ & 87.8 & 66.3 & 6.98 & 0.012 \\
\hline Refusal rate $(\%)$ & 12.2 & 12.7 & 1.42 & 0.72 \\
\hline
\end{tabular}

${ }^{1}$ Data are averaged over $7 \mathrm{~d}$ for 12 cows on each treatment.

${ }^{2}$ Fed at milking: feed delivery at milking time $(1400$ and $0700 \mathrm{~h})$, delayed feeding $=$ feed delivery with delay from milking time (1730 and $1030 \mathrm{~h}$ ).

${ }^{3}$ Standard error of the difference. 


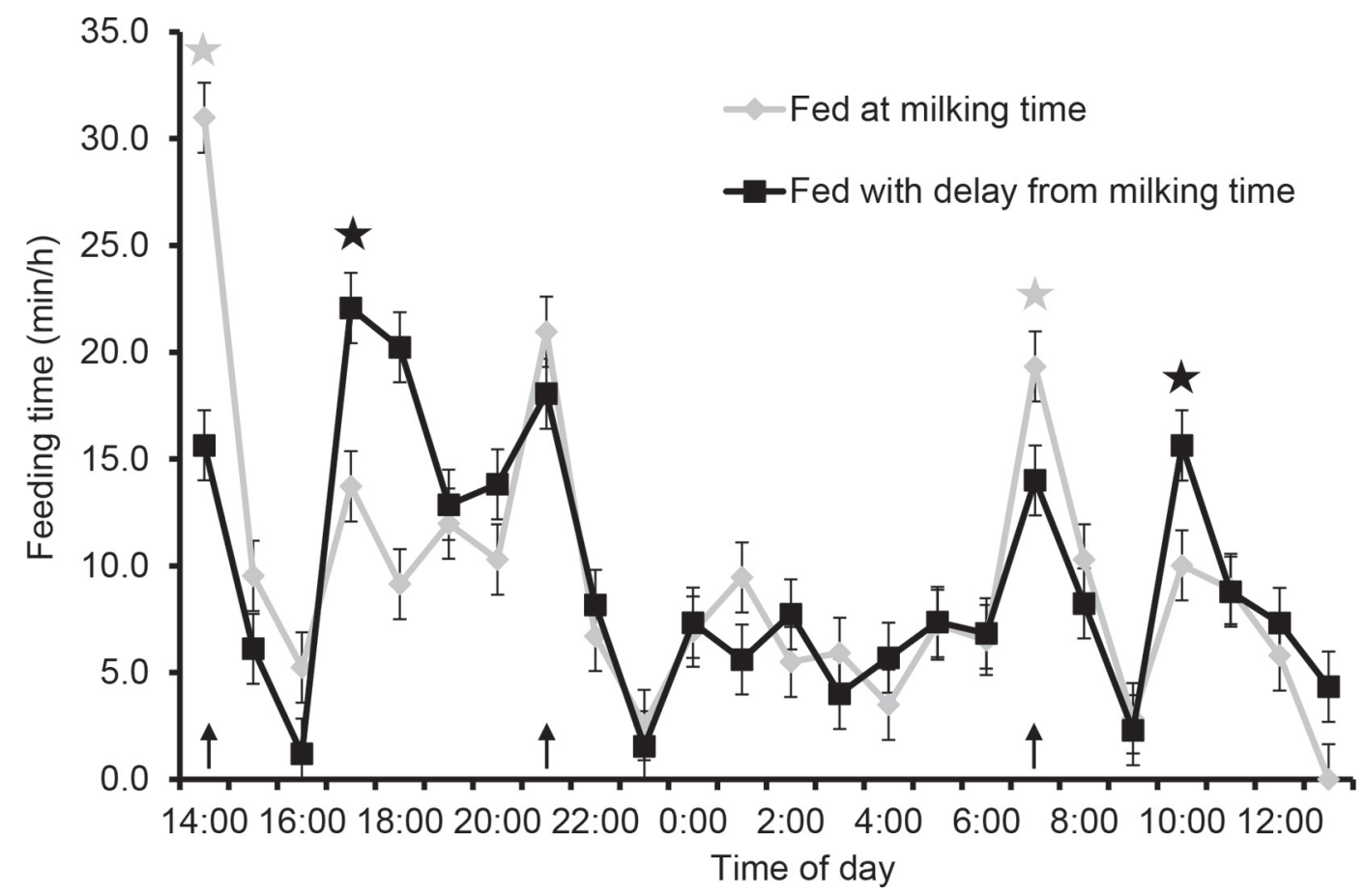

Figure 2. Hourly average feeding time \pm standard error (min) of lactating dairy cows fed 2 times per day: (1) at milking time (at 1400 and $0700 \mathrm{~h}$, denoted with gray star) or (2) fed with delay from milking time (at 1730 and $1030 \mathrm{~h}$, denoted with black star). Cows were milked 3 times per day at 1400, 2100, and $0700 \mathrm{~h}$ (denoted with $\uparrow$ ). Data are averaged over $7 \mathrm{~d}$ for 12 cows on each treatment.

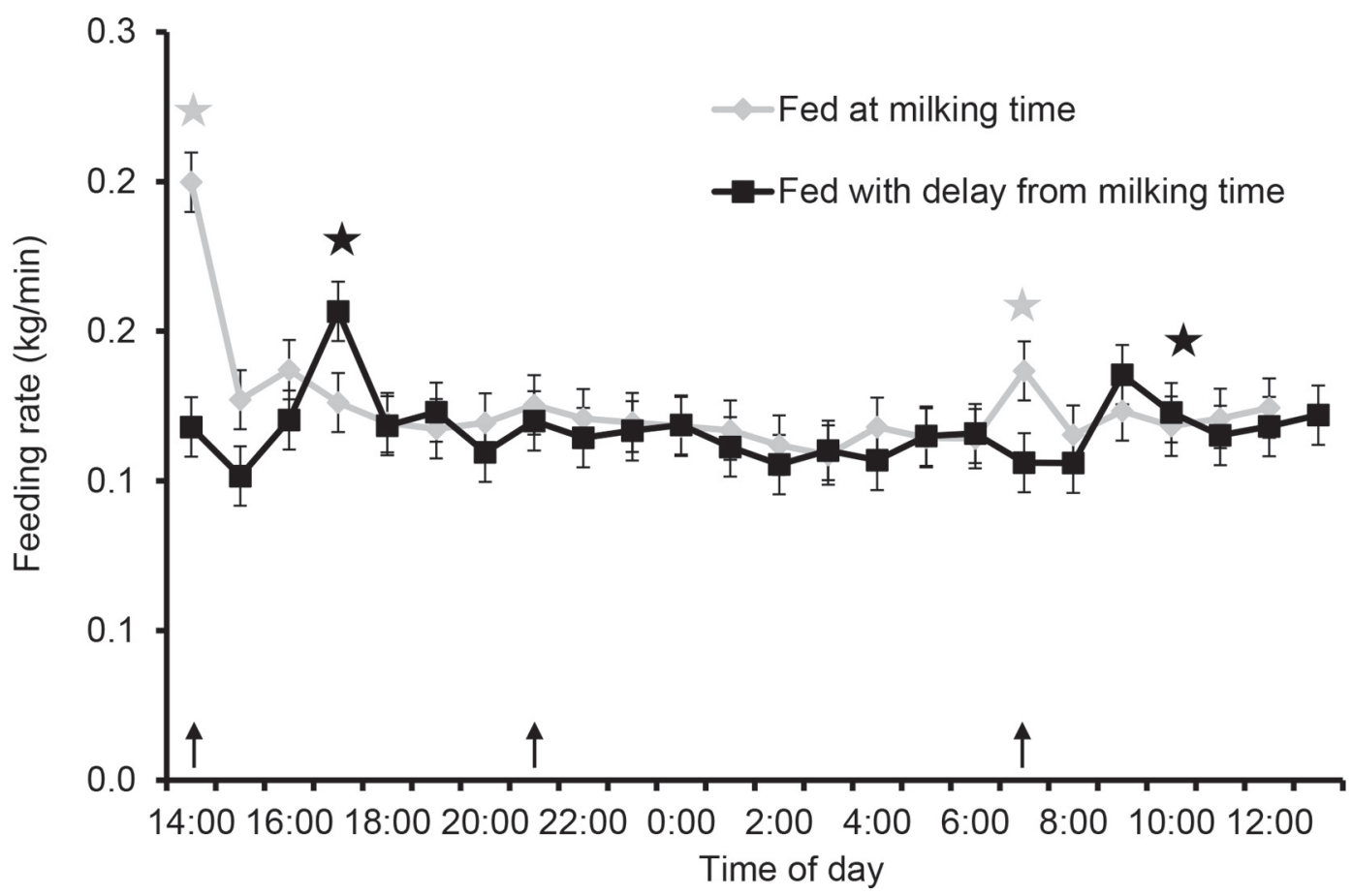

Figure 3. Hourly average feeding rate \pm standard error $(\mathrm{kg} / \mathrm{min})$ of lactating dairy cows fed 2 times per day: (1) at milking time (at 1400 and $0700 \mathrm{~h}$, denoted with gray star) or (2) fed with delay from milking time (at 1730 and $1030 \mathrm{~h}$, denoted with black star). Cows were milked 3 times per day at 1400, 2100, and $0700 \mathrm{~h}$ (denoted with $\uparrow$ ). Data are averaged over $7 \mathrm{~d}$ for 12 cows on each treatment. 
that the distribution of rumination time did vary across the day depending on treatment (Figure 4).

When cows were fed with a delay from milking time, DMI tended to be $0.7 \mathrm{~kg} / \mathrm{d}$ lower (Table 5). Although the timing of feed delivery had no effect on milk yield, milk components, SCC, or MUN, we did observe greater efficiency of milk production when cows were fed with a delay from milking time.

\section{DISCUSSION}

This study observed the behavior and productivity of lactating dairy cows in response to different feed delivery schedules, either with feed delivery coinciding with milking time or delayed $3.5 \mathrm{~h}$ from milking. Time budget allocation to various behaviors was similar between treatments; however, the patterning of these activities varied by treatment. In particular, feeding time differed throughout the day with the greatest feeding activity observed after the time points when feed was delivered, depending on treatment. Despite this, daily feeding time did not differ by treatment in the current study. In contrast, DeVries and von Keyserlingk (2005) found that cows spent $12.5 \%$ more time per day feeding with a 6 -h feed delay. The increase in feeding time in that previous study was attributed to a greater response in feeding time within the first hour after feed delivery. This was not the case in the current study given similar size and length of meals postfeed delivery between treatments. It is possible that the social feeding environment used by DeVries and von Keyserlingk (2005), rather than individually assigned feeding bins as used in the current study, had a greater effect on stimulating feeding activity; further work is needed to address this hypothesis.

Given a tendency for decreased DMI, and consistent feeding time, the average rate of feed consumption was slower throughout the day when feed delivery was delayed. This was mainly due to a spike at $1400 \mathrm{~h}$ for cows fed at milking, compared with a much more consistent rate of intake throughout the day for cows with a delayed feeding. DeVries and von Keyserlingk (2005) reported that cows on a feed delay consumed comparable DMI with increased feeding time/d, implying a similar slower rate of intake; however, those researchers did not have individual DMI, and thus could not report feeding rate. Benefits of the reduced rate of feed consumption observed in the current study include greater salivation rates with eating, thus improving buffering capacity of the rumen (Burt and Dunton, 1967; Beauchemin et al., 2008). Using estimates of salivation, while eating a diet similar in forage content, from Maekawa et al. (2002),

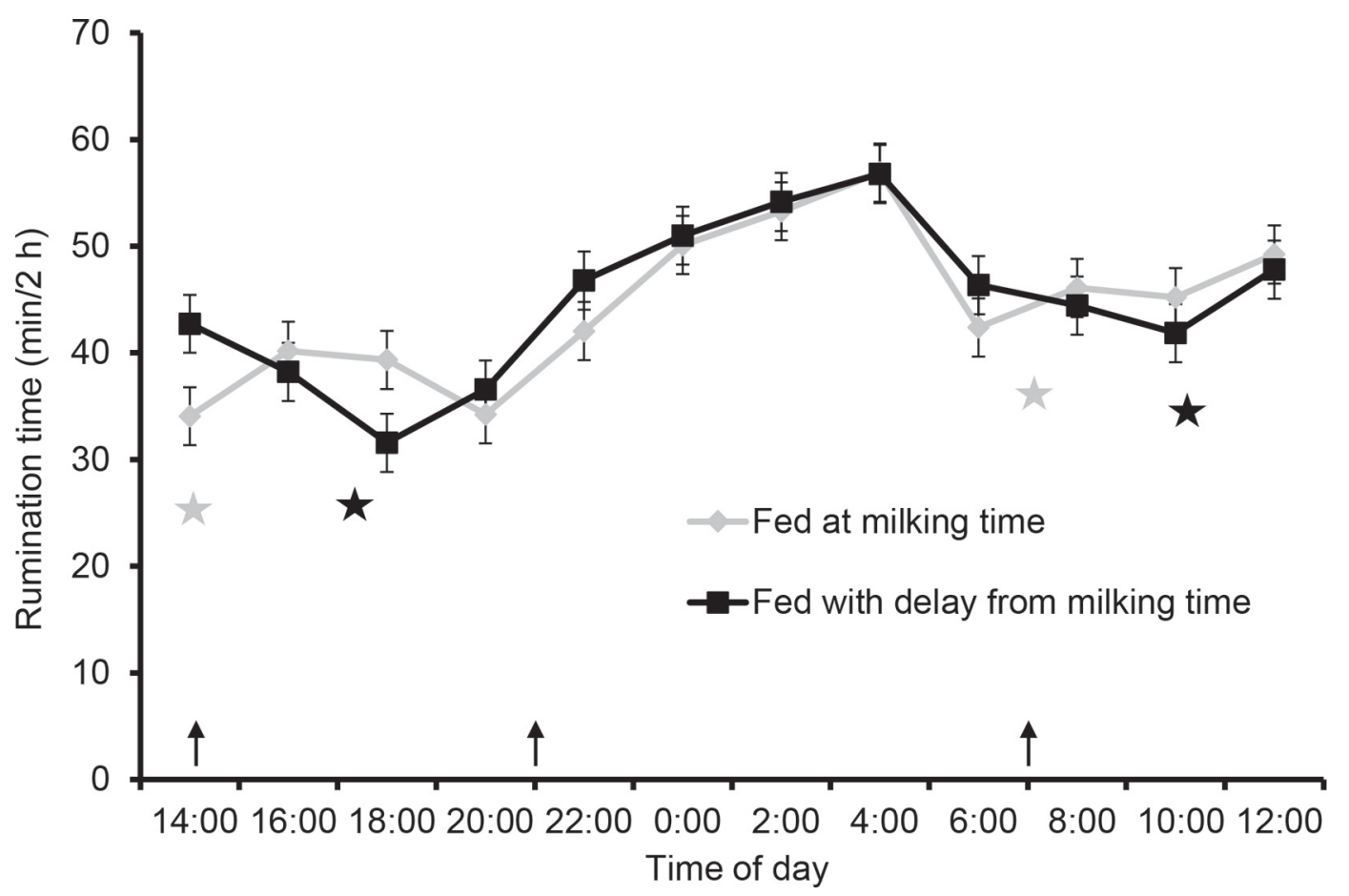

Figure 4. Bihourly average rumination time \pm standard error (min) of lactating dairy cows fed 2 times per day: (1) at milking time (at 1400 and $0700 \mathrm{~h}$, denoted with gray star) or (2) fed with delay from milking time (at 1730 and $1030 \mathrm{~h}$, denoted with black star). Cows were milked 3 times per day at 1400, 2100, and $0700 \mathrm{~h}$ (denoted with $\uparrow$ ). Data are averaged over $7 \mathrm{~d}$ for 12 cows on each treatment. 
Table 4. Effect of timing of feed delivery on the sorting $(\%)^{1,2}$ of long, medium, short, and fine particles ${ }^{3}$

\begin{tabular}{lcccc}
\hline & \multicolumn{2}{c}{ Treatment $^{4}$} & & \\
\cline { 2 - 3 } $\begin{array}{l}\text { Sorting of particle } \\
\text { fractions (\%) }\end{array}$ & $\begin{array}{c}\text { Fed at } \\
\text { milking }\end{array}$ & $\begin{array}{c}\text { Delayed } \\
\text { feeding }\end{array}$ & SED $^{5}$ & $P$-value \\
\hline Long & $102.3^{*}$ & 98.6 & 1.65 & 0.02 \\
Medium & $102.7^{*}$ & $102.3^{*}$ & 0.29 & 0.15 \\
Short & 96.9 & 97.9 & 0.67 & 0.16 \\
Fine & $96.6^{*}$ & $97.6^{*}$ & 0.69 & 0.16 \\
\hline
\end{tabular}

${ }^{1}$ Sorting $\%=100 \times(\mathrm{n}$ DMI $/ \mathrm{n}$ predicted DMI), where $\mathrm{n}=$ particle fraction (long, medium, short, or fine). Sorting values equal to $100 \%$ indicate no sorting, $<100 \%$ indicate selective refusals (sorting against), and $>100 \%$ indicate preferential consumption (sorting for). Data are averaged over $7 \mathrm{~d}$ for 12 cows on each treatment.

${ }^{2}$ Difference in individual sorting values (within treatment) from $100 \%$ expressed as $* P<0.05$; all other values are $P>0.05$.

${ }^{3}$ Particle size determined by the Penn State Particle Separator, which has a 19-mm screen (long), 8-mm screen (medium), 1.18-mm screen (short), and a pan (fine).

${ }^{4}$ Fed at milking: feed delivery at milking time $(1400$ and $0700 \mathrm{~h})$, delayed feeding $=$ feed delivery with delay from milking time (1730 and $1030 \mathrm{~h})$.

${ }^{5}$ Standard error of the difference.

a $10 \mathrm{~g}$ of $\mathrm{DM} / \mathrm{min}$ decrease in feeding rate across the day, as observed in the current study, would result in an extra $8.2 \mathrm{~L} / \mathrm{d}$ of saliva produced while eating. Such an increase, particularly in the hours after feed delivery, when the largest differences in feeding rates were observed, could help buffer the rumen and limit the drop in $\mathrm{pH}$ following these large meals (Beauchemin, 2007).
The average meal criterion for delayed feeding cows was $15.6 \mathrm{~min}$, which was $\sim 7$ min shorter in comparison to cows fed at milking. The meal criteria for cows fed at milking $(22.4 \mathrm{~min})$ is more comparable to those previously calculated in studies using similar automated feed bins when feed delivery took place at milking time (26.0 min: DeVries et al., 2007; 25.5 min: Hart et al., 2014).

Table 5. Effect of timing of feed delivery on DMI, milk yield, milk composition, and milk component yield, efficiency of production, MUN, and SCC

\begin{tabular}{|c|c|c|c|c|}
\hline \multirow[b]{2}{*}{ Item } & \multicolumn{2}{|c|}{ Treatment $^{1}$} & \multirow[b]{2}{*}{$\mathrm{SED}^{2}$} & \multirow[b]{2}{*}{$P$-value } \\
\hline & $\begin{array}{l}\text { Fed at } \\
\text { milking }\end{array}$ & $\begin{array}{l}\text { Delayed } \\
\text { feeding }\end{array}$ & & \\
\hline$\overline{\mathrm{DMI}^{3}(\mathrm{~kg} / \mathrm{d})}$ & 27.2 & 26.5 & 0.42 & 0.099 \\
\hline \multicolumn{5}{|l|}{ Milk yield (kg/d) } \\
\hline Milk $^{3}$ & 48.1 & 47.9 & 0.92 & 0.41 \\
\hline $4 \% \mathrm{FCM}^{4,5}$ & 45.0 & 45.5 & 1.24 & 0.72 \\
\hline $\mathrm{ECM}^{4}$ & 47.9 & 48.2 & 1.15 & 0.82 \\
\hline \multicolumn{5}{|l|}{ Milk composition $^{4}(\%)$} \\
\hline Fat & 3.60 & 3.68 & 0.14 & 0.57 \\
\hline Protein & 2.87 & 2.85 & 0.028 & 0.56 \\
\hline \multicolumn{5}{|l|}{ Milk component yield ${ }^{4}(\mathrm{~kg} / \mathrm{d})$} \\
\hline Fat & 1.72 & 1.76 & 0.067 & 0.54 \\
\hline Protein & 1.38 & 1.36 & 0.026 & 0.52 \\
\hline \multicolumn{5}{|l|}{ Efficiency of milk production $(\mathrm{kg} / \mathrm{kg})$} \\
\hline Milk/DMI ${ }^{3}$ & 1.80 & 1.93 & 0.066 & 0.05 \\
\hline $4 \% \mathrm{FCM} / \mathrm{DMI}^{4}$ & 1.67 & 1.83 & 0.047 & 0.014 \\
\hline $\mathrm{ECM} / \mathrm{DMI}^{4}$ & 1.79 & 1.93 & 0.048 & 0.013 \\
\hline MUN (mg/dL) & 10.7 & 10.6 & 0.45 & 0.88 \\
\hline $\log \operatorname{SCC}^{5 / 21}$ & 10.7 & 10.6 & 0.18 & 0.31 \\
\hline Retransformed SCC $(\times 1,000$ cells $/ \mathrm{mL})$ & 44.0 & 39.0 & - & - \\
\hline
\end{tabular}

${ }^{1}$ Fed at milking: feed delivery at milking time $(1400$ and $0700 \mathrm{~h})$, delayed feeding $=$ feed delivery with delay from milking time (1730 and $1030 \mathrm{~h})$.

${ }^{2}$ Standard error of the difference.

${ }^{3}$ Data are averaged over $7 \mathrm{~d}$ for 12 cows on each treatment.

${ }^{4}$ Data are averaged over $2 \mathrm{~d}$ for 12 cows on each treatment.

${ }^{5}$ Somatic cell counts (cells $/ \mathrm{mL}$ ) were log-transformed, given that they did not meet the assumption of normality. 
The shorter meal criteria with a feed delay suggest that delayed feeding cows had fewer, longer within meal nonfeeding intervals, indicating that they were eating more efficiently within meals. As a result of this difference in meal criteria length, cows fed with a delay from milking time consumed $\sim 1$ more meal per day, and meals were $\sim 10 \%$ smaller and shorter in comparison to cows fed at milking. The biological implications of these changes in meal patterning are not well established; Johnston and DeVries (2015) recently demonstrated, in a multi-study analysis, that each additional meal per day in highproducing dairy cows was associated with $+0.02 \mathrm{~kg} / \mathrm{d}$ of milk fat yield and tended to be associated with +0.2 $\mathrm{kg} / \mathrm{d}$ of DMI and $+0.3 \mathrm{~kg} / \mathrm{d}$ of milk yield. Similar to slowing the rate of intake, more frequent, smaller meals may benefit the rumen by spreading out the supply of nutrients, by avoiding harmful fluctuations in rumen $\mathrm{pH}$, or both, reducing the risk of subacute ruminal acidosis (Burt and Dunton, 1967; Yang and Varga, 1989; Shabi et al., 1999; Krause and Oetzel, 2006). Because no direct measures of the rumen environment were taken in the present study, further research is needed to assess this.

Meal patterning was not only altered with respect to daily averages, but also at specific time points of the day. Larger, longer meals were observed following milking when feed was also delivered at those times; this supports the findings of DeVries and von Keyserlingk (2005) that having fresh delivery coinciding with milking provides a stronger stimulus for cows to feed than milking alone. Given that meal size postfeed delivery was similar between treatments, we can conclude that fresh feed delivery is not only a relatively stable driver of feeding activity in the presence or absence of milking, but also that fresh feed delivery is the stronger stimuli for feeding activity, also corroborating the results of DeVries and von Keyserlingk (2005).

Although daily rumination time was similar between treatments, variation by treatment throughout the day was observed, reflecting the times at which the largest differences in feed consumption occurred across the day (i.e., after the 1400 and $1730 \mathrm{~h}$ feed deliveries). This is comparable to the findings of Hart et al. (2014), who reported no difference in daily rumination, but an alteration in the timing of rumination in response to the feed delivery frequency across the day.

Consistent with the findings of other researchers (DeVries and von Keyserlingk, 2005; Hart et al., 2014), daily lying time was unaffected by feeding strategy. This provides further support to the idea that lying time, which has a higher priority over feeding (Munksgaard et al., 2005), is relatively inflexible in response to changes in feeding patterns. In support of our hypothesis, latency to lie down after milking tended to be increased by 23 min after the $1400 \mathrm{~h}$ milking for cows with fresh feed at that time, coinciding with those cows having a meal that was 25 min longer at that time. Similarly, latency to lie down after milking was increased by $21.4 \mathrm{~min}$ after the $0700 \mathrm{~h}$ milking for cows with fresh feed at that time, coinciding with those cows having a longer meal (+14.1 min) at that time. DeVries and von Keyserlingk (2005) similarly reported that cows fed at milking time remained standing for $20 \mathrm{~min}$ longer than those without fresh feed.

Timing of feed delivery had no effect on the sorting of medium, short, or fine particles in the ration. A difference was found between treatments in sorting of the long ration particles; given low total amount of long particles in the ration $(<2 \%)$, no biological implications of this difference in sorting would be expected.

Whereas milk yield, 4\% FCM, and ECM were similar between treatments, improved efficiency of milk production (by $>7 \%$ ) was observed in the delayed feeding treatment. This improvement in efficiency is over $2.5 \times$ greater than that observed for monensin use in lactating dairy cows (2.5\%; Duffield et al., 2008), and thus has the potential to affect profitability at the farm level (Rodriguez et al., 2012). The improvement in efficiency observed in the current study was driven by the tendency for reduced DMI for cows on the feed delay treatment. Reduced DMI and maintenance of milk production has been similarly observed by Mantysaari et al. (2006) in a study comparing cows fed 1 time per day with those fed 5 times per day. Those authors suggested that with once-a-day feeding, larger meal size, and concurrent changes in ruminal fermentation affect diet digestibility. Other studies of feed delivery frequency have shown decreased digestibility of DM and NDF with less frequent feeding (Shabi et al., 1999; Dhiman et al., 2002). As discussed above, the reduced overall rate of feed consumption and smaller, more frequent meals throughout the day in the present study should promote a more stable rumen environment. With the feed delay, it is possible that more stable rumen conditions led to improved efficiency of nitrogen utilization and retention, as well as better fiber and crude protein digestibility, increasing VFA absorption, energy, and protein acquired from feed, and microbial protein synthesis (Burt and Dunton, 1967; Shabi et al., 1999; Dijkstra et al., 2012). This, in turn, may have had positive effects on milk production efficiency. An improvement in the efficiency of nutrient utilization would have been supported by lower MUN values when cows were fed with a delay from milking time; unfortunately, no difference in MUN was observed. Further, as measures of rumen kinetics were not made in the current study, more research is needed to further test these hypotheses. 


\section{CONCLUSIONS}

Delivering feed separately from milking time did not affect the daily time budget of dairy cows, but did affect the diurnal patterns of behavior. Providing fresh feed away from milking time encouraged cows to eat smaller, more frequent meals, more slowly throughout the day. These patterns may have promoted a more stable rumen environment, as reflected by improved efficiency of milk production.

\section{ACKNOWLEDGMENTS}

Thank you to the research and barn staff at the University of Guelph, Kemptville Campus Dairy Education and Innovation Center (Kemptville, ON, Canada). Special thanks go to Albert Koekkoek, Lisa Gordon, Geisa Mainardes, Morgan Overvest, Emily Kaufman, Megan Bruce, and Jessica Carriere from the University of Guelph, Kemptville Campus (Kemptville, ON, Canada). This project was financially supported by a Natural Sciences and Engineering Research Council of Canada (NSERC; Ottawa, ON, Canada) Collaborative Research and Development Grant with the Dairy Farmers of Ontario (Mississauga, ON, Canada) and an Ontario Ministry of Agriculture and Food (OMAF; Guelph, ON, Canada)/University of Guelph Production Systems research grant. Additional project support was received from the Canadian Foundation for Innovation (CFI; Ottawa, ON, Canada) and the Ontario Research Fund (Toronto, ON, Canada).

\section{REFERENCES}

AOAC International. 2000. Official Methods of Analysis. Vol. I. 17th ed. AOAC International, Arlington, VA.

Barnouin, J., M. Chassagne, S. Bazin, and D. Boichard. 2004. Management practices from questionnaire surveys in herds with very low somatic cell score through a national mastitis program in France. J. Dairy Sci. 87:3989-3999.

Beauchemin, K. A. 2007. Ruminal acidosis in dairy cows: Balancing physically effective fiber with starch availability. Pages 16-27 in Proc. Florida Ruminant Nutrition Symp., Gainesville, FL. University of Florida, Gainesville.

Beauchemin, K. A., L. Eriksen, P. Nørgaard, and L. M. Rode. 2008. Salivary secretion during meals in lactating dairy cattle. J. Dairy Sci. 91:2077-2081.

Burt, A. W. A., and C. R. Dunton. 1967. Effect of frequency of feeding upon food utilization by ruminants. Proc. Nutr. Soc. 26:181-190.

CCAC. 2009. Guidelines on: The care and use of farm animals in research, teaching and testing. Canadian Council on Animal Care, Ottawa, ON, Canada.

Chapinal, N., D. M. Veira, D. M. Weary, and M. A. G. von Keyserlingk. 2007. Technical note: Validation of a system for monitoring individual feeding and drinking behavior and intake in group housed dairy cows. J. Dairy Sci. 90:5732-5736.

DeVries, T. J., K. A. Beauchemin, and M. A. G. von Keyserlingk. 2007. Dietary forage concentration affects the feed sorting behavior of lactating dairy cows. J. Dairy Sci. 90:5572-5579.
DeVries, T. J., F. Dohme, and K. A. Beauchemin. 2008. Repeated ruminal acidosis challenges in lactating dairy cows at high and low risk for developing acidosis: Feed sorting. J. Dairy Sci. 91:3958 3967.

DeVries, T. J., S. Dufour, and D. T. Scholl. 2010. Relationship between feeding strategy, lying behavior patterns, and incidence of intramammary infection in dairy cows. J. Dairy Sci. 93:1987-1997.

DeVries, T. J., and M. A. G. von Keyserlingk. 2005. Time of feed delivery affects the feeding and lying patterns of dairy cows. J. Dairy Sci. 88:625-631.

DeVries, T. J., M. A. G. von Keyserlingk, and K. A. Beauchemin. 2003a. Short communication: Diurnal feeding pattern of lactating dairy cows. J. Dairy Sci. 86:4079-4082.

DeVries, T. J., M. A. G. von Keyserlingk, and K. A. Beauchemin. 2005. Frequency of feed delivery affects the behaviour of lactating dairy cows. J. Dairy Sci. 88:3553-3562.

DeVries, T. J., M. A. G. von Keyserslingk, D. M. Weary, and K. A. Beauchemin. 2003b. Measuring the feeding behaviour of lactating dairy cows in early to peak lactation. J. Dairy Sci. 86:3354-3361.

Dhiman, T. R., M. S. Zaman, I. S. MacQueen, and R. L. Boman. 2002. Influence of corn processing and frequency of feeding on cow performance. J. Dairy Sci. 85:217-226.

Dijkstra, J., J. L. Ellis, E. Kebreab, A. B. Strathe, S. Lopez, J. France, and A. Bannink. 2012. Ruminal pH regulation and nutritional consequences of low pH. Anim. Feed Sci. Technol. 172:22-33.

Duffield, T. F., A. R. Rabiee, and I. J. Lean. 2008. A meta-analysis of the impact of monensin in lactating dairy cattle. Part 2. Production effects. J. Dairy Sci. 91:1347-1360.

Hall, M. B. 2009. Analysis of starch, including maltooligosaccharides, in animal feeds: a comparison of methods and a recommended method for AOAC collaborative study. J. AOAC Int. 92:42-49.

Hart, K. D., B. W. McBride, T. F. Duffield, and T. J. DeVries. 2013. Effect of milking frequency on the behavior and productivity of lactating dairy cows. J. Dairy Sci. 96:6973-6985.

Hart, K. D., B. W. McBride, T. F. Duffield, and T. J. DeVries. 2014. Effect of frequency of feed delivery on the behavior and productivity of lactating dairy cows. J. Dairy Sci. 97:1713-1724.

Johnston, C., and T. J. DeVries. 2015. Associations of behavior and production in lactating dairy cows. J. Dairy Sci. 2(E-Suppl.):450-451.

Kononoff, P. J., A. J. Heinrichs, and D. R. Buckmaster. 2003. Modification of Penn State forage and total mixed ration particle separator and the effects of moisture content on its measurement. J. Dairy Sci. 86:1858-1863.

Krause, K. M., and G. R. Oetzel. 2006. Understanding and preventing subacute ruminal acidosis in dairy herds: A review. Anim. Feed Sci. Technol. 126:215-236.

Ledgerwood, D. N., C. Winckler, and C. B. Tucker. 2010. Evaluation of data loggers, sampling intervals, and editing techniques for measuring the lying behavior of dairy cattle. J. Dairy Sci. 93:5129-5139.

Leonardi, C., and L. E. Armentano. 2003. Effect of quantity, quality, and length of alfalfa hay on selective consumption by dairy cows. J. Dairy Sci. 86:557-564.

MacDonald, P. D. M., and P. E. J. Green. 1988. User's Guide to Program MIX: An interactive program for fitting mixtures of distributions. Release 2.3, January 1988. Ichthus Data Systems, Hamilton, Ontario, Canada.

Maekawa, M., K. A. Beauchemin, and D. A. Christensen. 2002. Effect of concentrate level and feeding management on chewing activities, saliva production, and ruminal $\mathrm{pH}$ of lactating dairy cows. J. Dairy Sci. 85:1165-1175.

Mantysaari, P., H. Khalili, and J. Sariola. 2006. Effect of feeding frequency of a total mixed ration on the performance of high-yielding dairy cows. J. Dairy Sci. 89:4312-4320.

Melin, M., H. Wiktorsson, and L. Norell. 2005. Analysis of feeding and drinking patterns of dairy cows in two cow traffic situations in automatic milking systems. J. Dairy Sci. 88:71-85.

Morris, T. R. 1999. Experimental Design and Analysis in Animal Sciences. CABI Publishing, New York, NY. 
Munksgaard, L., M. B. Jensen, L. J. Pedersen, S. W. Hansen, and L. Matthews. 2005. Quantifying behavioural priorities-Effects of time constraints on behaviour of dairy cows, Bos taurus. Appl. Anim. Behav. Sci. 92:3-14.

NRC. 2001. Nutrient Requirements for Dairy Cattle. Natl. Acad. Sci. Washington, DC.

Rodriguez, L., G. Bethard, D. Tomlinson, and M. McGilliard. 2012. Impact of milk yield, herd size, and feed efficiency on economic change between and within California dairies from 2006 through 2010. J. Dairy Sci. 95(E-Suppl. 2):398.

SAS Institute Inc. 2013. SAS version 9.4. SAS Institute Inc., Cary, NC

Schirmann, K., M. A. G. von Keyserlingk, D. M. Weary, D. M. Veira, and W. Heuwieser. 2009. Technical note: Validation of a system for monitoring rumination in dairy cows. J. Dairy Sci. 92:6052-6055.

Shabi, Z., I. Bruckental, S. Zamwell, H. Tagari, and A. Arieli. 1999 Effects of extrusion of grain and feeding frequency on rumen fermentation, nutrient digestibility, and milk yield and composition in dairy cows. J. Dairy Sci. 82:1252-1260.
Tyler, J. W., L. K. Fox, S. M. Parish, J. Swain, D. L. Johnson, H. A Grasseschi, and R. Gant. 1997. Effect of feed availability on postmilking standing time in dairy cows. J. Dairy Res. 64:617-620.

Tyrrell, H. F., and J. T. Reid. 1965. Prediction of the energy value of cow's milk. J. Dairy Sci. 48:1215-1223.

Van Soest, P. J., J. B. Robertson, and B. A. Lewis. 1991. Methods for dietary fiber, neutral detergent fiber and nonstarch polysaccharide in relation to animal nutrition. J. Dairy Sci. 74:3583-3597.

Watters, M. E. A., H. W. Barkema, K. E. Leslie, M. A. G. von Keyserlingk, and T. J. DeVries. 2014. Relationship between postmilking standing duration and risk of intramammary infection in freestall-housed dairy cows milked 3 times per day. J. Dairy Sci. 97:3456-3471.

Yang, C. M., and G. A. Varga. 1989. Effect of three concentrate feeding frequencies on rumen protozoa rumen digesta kinetics and milk yield in dairy cows. J. Dairy Sci. 72:950-957. 